\title{
Interactive effects of increased intake of saturated fat and cholesterol on atherosclerosis in the Japanese quail (Coturnix japonica)
}

\author{
Yvonne V. Yuan ${ }^{1} *$, David D. Kitts ${ }^{1} \dagger$ and David V. Godin ${ }^{2}$ \\ ${ }^{1}$ Department of Food Science, Faculty of Agricultural Sciences, University of British Columbia, 6650 NW Marine Drive, \\ Vancouver, British Columbia, Canada V6T $1 Z 4$ \\ ${ }^{2}$ Department of Pharmacology and Therapeutics, Faculty of Medicine, University of British Columbia, \\ 2176 Health Sciences Mall, Vancouver, British Columbia, Canada V6T 1Z3
}

(Received 16 July 1997 - Revised 19 November 1997 - Accepted 27 November 1997)

\begin{abstract}
Increasing the energy value of diets with dietary fat, particularly fats rich in saturated fatty acids, can result in the elevation of plasma total and lipoprotein cholesterol. In the present study, experimental diets were designed to examine the effects of increasing the energy content of diets with a saturated fat source and cholesterol in a non-purified diet on hyperlipoproteinaemia and aortic plaque composition in the atherosclerosis-susceptible Japanese quail (Coturnix japonica) model of human atherosclerosis. Commercial poultry diets containing two levels (i.e. 60 or $120 \mathrm{~g} /$ $\mathrm{kg}$ ) of beef tallow as the primary source of saturated fat were balanced for endogenous cholesterol or supplemented with cholesterol (i.e. 0.5 or $5 \cdot 0 \mathrm{~g} / \mathrm{kg}$ ) and fed to quail for 9 weeks to examine the effects on whole plasma, lipoprotein and aortic plaque lipid composition in relation to aortic plaque formation. Hypercholesterolaemia $(P<0.001)$ was confirmed in birds fed on highcholesterol (HC) diets only. An interaction $(P=0 \cdot 05)$ between dietary cholesterol and fat intake level was observed for plasma triacylglycerols (TG) and was specific to changes observed in VLDL composition. Diet-induced changes in lipoprotein total cholesterol, TG and phospholipid composition were greatest in the portomicron and VLDL fractions in birds fed on atherogenic diets. Hyperlipoproteinaemia induced by the $60 \mathrm{~g} / \mathrm{kg}$ added beef tallow-HC diet resulted in significant $(P<0 \cdot 001)$ aortic plaque deposition, which was further enhanced in birds fed on the $120 \mathrm{~g} / \mathrm{kg}$ beef tallow-HC diet. Quail fed on $120 \mathrm{~g} / \mathrm{kg}$ beef tallow-HC diets exhibited the most severe aortic plaque formation, with marked increases in aortic tissue cholesterol content and quantifiable amounts of several cholesterol oxides (5,6 $\alpha$-epoxy- $5 \alpha$-cholesterol, $7 \beta$-hydroxycholesterol, cholestanetriol, 7-ketocholesterol and 25-hydroxycholesterol). In summary, hyperlipoproteinaemia associated with $\mathrm{HC}$ diets with a greater proportion of energy from saturated fat produced a combined effect in altering plasma and lipoprotein lipid composition as well as aortic tissue cholesterol and cholesterol oxide content in the Japanese quail.
\end{abstract}

\section{Atherosclerosis: Japanese quail: Lipoproteins: Cholesterol}

Evidence from epidemiological (Lipid Research Clinic Program, 1984; Castelli, 1986), clinical (Schaefer et al. 1981; Mustad et al. 1997) and animal (Fernandez \& McNamara, 1991, 1994; Nishina et al. 1993; Yuan et al. 1997) studies have indicated a strong association between hyperlipoproteinaemia and the intake level, source and cholesterol content of dietary fat. Common to findings from both animal (Lin et al. 1992; Mott et al. 1992) and human (Shepherd et al. 1980; Mattson \& Grundy, 1985; Kris-Etherton et al. 1993) studies have been the elevation of LDL-cholesterol levels and apparent reduction of LDL receptors (Mustad et al. 1997) observed in subjects fed on diets rich in saturated fat and/or cholesterol. Experiments conducted in both the monkey and gerbil have indicated the importance of the relative $14: 0$ to $18: 2 n-6$ fatty acid ratio in particular, as well as dietary cholesterol, in producing hypercholesterolaemia (Khosla \& Hayes, 1993; Pronczuk et al. 1994). These studies have also indicated that the presence of cholesterol in the diet can produce a further increase in plasma cholesterol associated specifically with 16 : 0 , which does not occur when cholesterol is absent from the diet. Feeding cholesterol alone (Ohtani et al. 1990), or

\footnotetext{
Abbreviations: apo, apolipoprotein; GC-MS, gas chromatography - mass spectroscopy; HC, high cholesterol; P : S, polyunsaturated : saturated fatty acid ratio; PL, phospholipid; TC, total cholesterol; TG, triacylglycerol; TS diet, Turkey Starter diet.

*Present address: Department of Nutritional Sciences, Faculty of Medicine, University of Toronto, 150 College Street, Toronto, ON, Canada M5S 3E2.

†Corresponding author: Dr David Kitts, fax +1 604822 3959, email ddkitts@unixg.ubc.ca
} 
in combination with saturated fat, also suppresses LDL receptors in rodents (Spady \& Dietschy, 1988). Modifying animal fat sources by removing endogenous sterols or blending with vegetable or oilseed lipids rich in $18: 2 n-6$ have been successful in neutralizing the hypercholesterolaemic potential of animal fats containing saturated fatty acids (Hunt et al. 1992; Seppanen-Laakso et al. 1992; Sundram et al. 1995; Hayes et al. 1995). Moreover, the putative role of hypertriacylglycerolaemia as an independent risk factor in the development of heart disease (Castelli, 1986; Austin, 1991) may also involve an interaction between cholesterol and dietary fat intake. For example, dietary cholesterol has been shown to reduce fatty acid oxidation, which in turn increases the levels of hepatic and plasma triacylglycerols (TG) (Fungwe et al. 1993). Despite the interactive effects of dietary fat and cholesterol on plasma lipids (Lin et al. 1992), only a few studies have attempted to examine the significance of this interaction on lipoprotein composition and the severity of atherosclerosis (Mott et al. 1992; Nishina et al. 1993).

Animal models such as the atherosclerosis-susceptible White Carneau pigeon (Columba livia), Japanese quail (Coturnix japonica) and the apolipoprotein (apo)-E null mutant mouse have been valuable in studying diet-induced development of atherogenesis as associated with hyperlipoproteinaemia and aortic plaque development (Clarkson et al. 1962; Nishina et al. 1993; Godin et al. 1994). Feeding cholesterol- and cholic acid-supplemented diets has been shown to accelerate the formation of aortic plaque in the apo-E null mutant mouse (Nishina et al. 1993) and quail (Yuan et al. 1997), thus indicating the requirement for hypercholesterolaemia for accelerated atherosclerotic plaque development. Recently, we have confirmed the findings of other workers (Radcliffe \& Tramposch, 1988; Godin et al. 1994) that the Japanese quail also develops hypercholesterolaemia and atherosclerotic plaque when fed on diets containing a moderate level of varying fat sources supplemented with cholesterol, and have extended these studies by describing the changes in lipoprotein composition of hypercholesterolaemic birds (Yuan et al. 1997). Despite the predominance of HDL in the Japanese quail compared with the predominance of LDL in man, the composition and histopathological characteristics of aortic plaque have been noted to be similar to the situation in human atherosclerosis (Shih et al. 1983).

The purpose of the present study was to use the atherosclerosis-susceptible Japanese quail model to examine further both the independent and interactive effects of increased energy consumption from a saturated fat source (e.g. beef tallow) with varying levels of cholesterol, on plasma and lipoprotein lipid composition and the development and composition of atherosclerotic plaque.

\section{Materials and methods}

\section{Animals and diets}

Sixty, 6-week-old male atherosclerosis-susceptible Japanese quail (Coturnix japonica; University of British Columbia Quail Genetic Resource Centre, Vancouver, BC, Canada) were randomly assigned to one of five dietary treatment groups ( $n 12$ in each group) consisting of a reference group (diet A) fed on a crumbled commercial Turkey Starter (TS) diet containing $54 \mathrm{~g}$ beef tallow/kg diet (Otter Co-op, Aldergrove, BC, Canada), two groups fed on TS supplemented with $6 \cdot 0 \mathrm{~g}$ beef tallow $/ \mathrm{kg}$ diet, to make a total of $60 \mathrm{~g}$ beef tallow $/ \mathrm{kg}$ diet (by calculation), containing either a low $(0.5 \mathrm{~g} / \mathrm{kg}$ diet; diet B) or high $(5.0 \mathrm{~g} / \mathrm{kg}$ diet; diet C) level of cholesterol, and two groups fed on TS supplemented with $66 \mathrm{~g}$ beef tallow $/ \mathrm{kg}$ diet to make a total of $120 \mathrm{~g}$ beef tallow/kg diet (by calculation), containing either a low $(0.5 \mathrm{~g} / \mathrm{kg}$ diet; diet D) or high $(5.0 \mathrm{~g} / \mathrm{kg}$ diet; diet E) level of cholesterol. Diets were formulated to have reduced polyunsaturated: saturated fatty acid (P:S) ratios, but to have similar $n-6: n-3$ ratios through the addition of the supplementary beef tallow.

The compositions of the commercial TS diets supplemented with beef tallow and cholesterol are summarized in Table 1. The basal TS diet was supplemented with beef tallow (Cargill Foods, High River, AB, Canada), which was slowly liquefied over gentle heat $\left(10-15 \mathrm{~min}, 45-50^{\circ}\right)$ and cholesterol and cholic acid $(2: 1)$ mixed in to ensure uniform distribution in the crumbled commercial diet following thorough mixing. The additional dietary fat and sterols were thoroughly mixed into diets in an aluminium mixing bowl using a Hobart mixer. After mixing, individual diets were stored in doubled, dark plastic bags in a walk-in freezer $\left(-15^{\circ}\right)$ throughout the experimental study. A sample of each experimental diet was taken for analysis of component fatty acids, gross energy and DM content. Diets were isonitrogenous, with diets A, B and C containing comparable levels of energy (17.21-17.97 MJ/kg; Table 1), and diets D and E containing a greater total energy $(18 \cdot 76-18.83 \mathrm{MJ} / \mathrm{kg})$ due to the higher fat content.

\section{Gross energy determination of diets}

The gross energy contents of the reference diet $\mathrm{A}$ and experimental diets $\mathrm{B}$ to $\mathrm{E}$ were determined by bomb calorimetry and corrected for the dry weight of the diet (Miller \& Payne, 1959).

\section{Fatty acid analysis of diets}

The fatty acid compositions of the reference diet $\mathrm{A}$ and supplemented experimental diets B, C, D and E as determined by GC are summarized in Table 2 . Samples were extracted according to the method of Folch et al. (1957), methylated with $\mathrm{BF}_{3}$ (Nwokolo \& Kitts, 1988) and analysed for component fatty acids using a Varian Model 3700 GC equipped with a $60 \mathrm{~m} \times 0.53 \mathrm{~mm}$ i.d. capillary column coated with $0 \cdot 25 \mu \mathrm{m}$ Supelcowax 10 (Supelco, Bellefont, PA, USA). A 17:0 fatty acid internal standard (Supelco) was included in the fatty acid analyses. Supplementation of the TS diet with beef tallow resulted in only slight increases in the overall saturated fatty acid $(16: 0$ and $18: 0)$ content, a relatively larger increase in monounsaturated fatty acid (primarily 18:1n-9) and a decrease in polyunsaturated fatty acid (18:2n-6 and $18: 3 n-3)$ content in diets D and $\mathrm{E}$ (Table 2). These changes in fatty acid composition of diets $\mathrm{D}$ and $\mathrm{E}$ resulted in a reduction in $\mathrm{P}: \mathrm{S}$ ratios, but similar $n-6: n-3$ ratios compared with the reference TS diet (diet A) and low-tallow diets B and C. 
Table 1. Composition and energy content of experimental diets*

\begin{tabular}{|c|c|c|c|c|c|}
\hline \multirow[b]{2}{*}{ Supplemented component (g/kg) } & \multicolumn{5}{|c|}{ Diets† } \\
\hline & A & $\mathrm{B}$ & C & $\mathrm{D}$ & $E$ \\
\hline $\begin{array}{l}\text { Beef tallow } \ddagger \\
\text { Naturally present } \\
\text { Added } \\
\text { Total }\end{array}$ & $\begin{array}{c}54 \cdot 0 \\
0 \\
54 \cdot 0\end{array}$ & $\begin{array}{r}54 \cdot 0 \\
6 \cdot 0 \\
60 \cdot 0\end{array}$ & $\begin{array}{r}54 \cdot 0 \\
6 \cdot 0 \\
60 \cdot 0\end{array}$ & $\begin{array}{r}54.0 \\
66.0 \\
120.0\end{array}$ & $\begin{array}{r}54.0 \\
66.0 \\
120.0\end{array}$ \\
\hline $\begin{array}{l}\text { Cholesterol } \\
\text { Naturally present } \\
\text { Added from beef tallow } \\
\text { Added from crystalline sources§ } \\
\text { Total }\end{array}$ & $\begin{array}{l}0.066 \\
- \\
- \\
0.066\end{array}$ & $\begin{array}{l}0.066 \\
0.008 \\
0.426 \\
0.5\end{array}$ & $\begin{array}{l}0.066 \\
0.008 \\
4.926 \\
5.0\end{array}$ & $\begin{array}{l}0.066 \\
0.081 \\
0.353 \\
0.5\end{array}$ & $\begin{array}{l}0 \cdot 066 \\
0.081 \\
4 \cdot 853 \\
5 \cdot 0\end{array}$ \\
\hline Cholic acid§ & - & $0 \cdot 25$ & $2 \cdot 5$ & $0 \cdot 25$ & $2 \cdot 5$ \\
\hline Crude lipid & $100 \cdot 0$ & $103 \cdot 0$ & $103 \cdot 0$ & $161 \cdot 0$ & $161 \cdot 0$ \\
\hline Gross energy (MJ/kg) & $17 \cdot 21$ & $17 \cdot 62$ & $17 \cdot 97$ & $18 \cdot 76$ & $18 \cdot 83$ \\
\hline
\end{tabular}

* Composition of reference diet A (Turkey Starter; Otter Co-op, Aldergrove, British Columbia, Canada) (g/kg diet): lucerne meal $15 \cdot 0$, maize 150 , distiller's grain $25 \cdot 0$, fish meal $50 \cdot 0$, lime $47 \cdot 0$, meat meal $75 \cdot 0$, pellet binder $15 \cdot 0$, multiphos $10 \cdot 0, \mathrm{NaCl} 2 \cdot 0$, soyabean meal 274 , beef tallow $54 \cdot 0$, wheat 278 , vitamins and minerals $5 \cdot 0$, methionine $0 \cdot 25$. The vitamin mixture supplied the following ( $\mathrm{mg} / \mathrm{kg}$ diet): thiamine hydrochloride $1 \cdot 0$, riboflavin $5 \cdot 0$, niacin 75 , pantothenic acid 10 , pyridoxine hydrochloride $3 \cdot 0$, choline 402 , pteroylmonoglutamic acid $1 \cdot 0$, D-biotin $0 \cdot 1$, cyanocobalamin $0 \cdot 0012$, menadione sodium bisulfite $1 \cdot 6$, D-calcium pantothenate 300 , retinyl palmitate 40 , cholecalciferol $8 \mu \mathrm{g}$, DL- $\alpha$-tocopherol acetate 120. The mineral mixture supplied the following (mg/kg diet): $\mathrm{K}_{2} \mathrm{HPO}_{4} 10600, \mathrm{NaH}_{2} \mathrm{PO}_{4} 2100, \mathrm{MgSO}_{4} .7 \mathrm{H}_{2} \mathrm{O} 1600, \mathrm{NaCl} 4600$, ferric citrate $90, \mathrm{KI} 30, \mathrm{MnSO}_{4} . \mathrm{H}_{2} \mathrm{O} 150$, $\mathrm{ZnCl}_{2} 20, \mathrm{CuSO}_{4} \cdot 5 \mathrm{H}_{2} \mathrm{O} 10$.

† Diets B, C, D and E are diet A with supplemented components. Cholesterol and cholic acid were added to liquefied beef tallow before mixing in with crumbled diet $A$.

$\ddagger$ Cargill Foods, High River, AB, Canada.

$\S$ ICN Biochemicals, Inc., Cleveland, OH, USA.

\section{Animal feeding studies}

Quail were housed in heated brooder cages $(0.9 \mathrm{~m}$ long, $0.46 \mathrm{~m}$ wide) with a single treatment group per cage. Birds had free access to feed and distilled deionized water. A $14 \mathrm{~h}$ dark $-10 \mathrm{~h}$ light cycle was maintained in the room. Daily

Table 2. Fatty acid profile of experimental diets

\begin{tabular}{|c|c|c|c|c|c|}
\hline \multirow{2}{*}{$\begin{array}{l}\text { Fatty acid ( } \mathrm{g} / 100 \mathrm{~g} \\
\text { total fatty acids) }\end{array}$} & \multicolumn{5}{|c|}{ Diets* } \\
\hline & $A$ & B & $\mathrm{C}$ & $\mathrm{D}$ & $E$ \\
\hline \multicolumn{6}{|l|}{ Saturated } \\
\hline Lauric (12:0) & $0 \cdot 1$ & $0 \cdot 1$ & $0 \cdot 1$ & $0 \cdot 1$ & $0 \cdot 1$ \\
\hline Myristic (14:0) & 1.5 & $1 \cdot 6$ & $1 \cdot 6$ & $2 \cdot 2$ & $2 \cdot 2$ \\
\hline Palmitic $(16: 0)$ & $21 \cdot 0$ & $21 \cdot 0$ & $21 \cdot 0$ & $22 \cdot 0$ & $22 \cdot 0$ \\
\hline Stearic $(18: 0)$ & $9 \cdot 8$ & $9 \cdot 7$ & $9 \cdot 7$ & $10 \cdot 8$ & $10 \cdot 8$ \\
\hline Arachidic $(20: 0)$ & $0 \cdot 3$ & $0 \cdot 3$ & $0 \cdot 3$ & 0.2 & 0.2 \\
\hline Behenic $(22: 0)$ & $1 \cdot 2$ & $1 \cdot 3$ & $1 \cdot 3$ & $1 \cdot 0$ & $1 \cdot 0$ \\
\hline \multicolumn{6}{|l|}{ Monounsaturated } \\
\hline Myristoleic (14:1) & 0.2 & 0.2 & 0.2 & $0 \cdot 4$ & 0.4 \\
\hline Palmitoleic (16:1) & $2 \cdot 9$ & $3 \cdot 0$ & $3 \cdot 2$ & $3 \cdot 3$ & $3 \cdot 3$ \\
\hline Oleic $(18: 1 n-9)$ & 37.9 & $37 \cdot 5$ & $37 \cdot 5$ & $40 \cdot 1$ & $40 \cdot 1$ \\
\hline Eicosenoic $(20: 1)$ & 0.9 & $1 \cdot 4$ & $1 \cdot 4$ & 0.9 & 0.9 \\
\hline \multicolumn{6}{|l|}{ Polyunsaturated } \\
\hline Linoleic (18:2n-6) & $20 \cdot 0$ & $19 \cdot 4$ & $19 \cdot 4$ & $15 \cdot 0$ & $15 \cdot 0$ \\
\hline Linolenic (18:3n-3) & $2 \cdot 3$ & $2 \cdot 4$ & $2 \cdot 4$ & $1 \cdot 8$ & $1 \cdot 8$ \\
\hline Arachidonic $(20: 4 n-6)$ & 0.2 & 0.2 & $0 \cdot 2$ & 0.2 & 0.2 \\
\hline Total saturates & 33.9 & $34 \cdot 0$ & $34 \cdot 0$ & $36 \cdot 3$ & $36 \cdot 3$ \\
\hline Total unsaturates & $64 \cdot 4$ & $64 \cdot 1$ & $64 \cdot 3$ & $61 \cdot 7$ & $61 \cdot 7$ \\
\hline $\mathrm{P}: \mathrm{S} \dagger$ & 0.66 & 0.65 & 0.65 & 0.47 & 0.47 \\
\hline$n-6: n-3 \neq$ & $8 \cdot 8$ & $8 \cdot 2$ & $8 \cdot 2$ & $8 \cdot 4$ & $8 \cdot 4$ \\
\hline
\end{tabular}

* Diet A, Turkey Starter (TS); B, TS + 0.5 g cholesterol $/ \mathrm{kg}$ diet; C, TS + 5.0 g cholesterol $/ \mathrm{kg}$ diet; D, TS $+66 \mathrm{~g}$ beef tallow $/ \mathrm{kg}$ diet $+0.5 \mathrm{~g}$ cholesterol $/ \mathrm{kg}$ diet; $\mathrm{E}, \mathrm{TS}+66 \mathrm{~g}$ beef tallow $/ \mathrm{kg}$ diet $+5 \cdot 0 \mathrm{~g}$ cholesterol $/ \mathrm{kg}$ diet. † Polyunsaturated : saturated fatty acid ratio.

$\ddagger n-6: n-3$ Polyunsaturated fatty acid ratio. replacement of diets minimized exposure of birds to oxidized dietary lipids. Animals were cared for in accordance with the principles of the Guide to the Care of Experimental Animals (Canadian Council of Animal Care, 1993). Following 9 weeks on their respective diets, birds were killed at 09.00 hours. After decapitation, trunk blood was collected in chilled heparinized tubes and centrifuged $(1000 \mathrm{~g} ; 5 \mathrm{~min}$ at $4^{\circ}$ ) for separation of plasma. Liver tissue was dissected, rinsed in $50 \mathrm{mM}$-Tris $0 \cdot 1 \mathrm{mM}$-EDTA buffer, $\mathrm{pH} 7.6$ and weighed before determination of total cholesterol (TC) and TG content (Boehringer Mannheim, Laval, PQ, Canada). Aortic tissue (the brachycephalic arteries to their bifurcations and the aorta to the iliac branching) was removed and opened lengthwise for examination of the presence of lesions on the lumen surface using a 10-30× dissecting microscope. Aortic lesions were assigned a score on a scale from 0 to 4 according to Shih et al. (1983), Godin et al. (1994) and Yuan et al. (1997). Scores were assigned by two independent investigators, in a blind fashion, according to the following scale: $0=$ clean surface; $1=\leq 5$ plaques; $2=6-20$ plaques and an affected area less than $50 \% ; 3=>20$ plaques with an affected area greater than $50 \% ; 4=$ massive atheromas observed. Following completion of scoring, aortic tissue was placed into chilled $50 \mathrm{mM}$-Tris $0.1 \mathrm{mM}$-EDTA buffer, $\mathrm{pH} 7 \cdot 6$ before determination of cholesterol oxides by $\mathrm{GC}$ with confirmation by mass spectrometry (GC-MS). Additional birds from each treatment group were used to provide aortic tissue specimens for scanning electron microscopy evaluation of aortic lumen wall morphology following plaque scoring as described earlier.

\section{Plasma and lipoprotein lipid analyses}

Plasma TC (Siedel et al. 1983),TG (Ziegenhorn, 1975), 
phospholipid (PL; Takayama et al. 1977) and protein (Bradford, 1976) were determined using standard methods (Boehringer Mannheim). Lipoproteins were separated from whole plasma by density gradient ultracentrifugation (Terpstra et al. 1982). Plasma lipoprotein fractions in samples from each treatment were visualized by running a reference tube pre-stained with Sudan black in ethylene glycol. Sucrose density gradient measurements and Sudan black staining of lipoprotein fractions in individual treatment reference samples were used to confirm the density gradients used in unstained samples. Quail fed on the highcholesterol (HC) diets exhibited a distinct lipid plug on the top $\left(\rho_{20}<1.006\right)$ of the centrifuge tube after ultracentrifugation which corresponded to the portomicron fraction. This fraction was carefully removed to prevent contamination of other fractions before their removal (Terpstra et al. 1982). Remaining lipoproteins were separated into five fractions at density ranges as follows: fraction $1,1.006<$ $\rho_{20}<1.020$; fraction $2,1 \cdot 030<\rho_{20}<1.046$; fraction 3 , $1.050<\rho_{20}<1.080$; fraction $4,1 \cdot 106<\rho_{20}<1 \cdot 184$; fraction $5, \rho_{20}>1.21$ using an SW 40Ti rotor at $272000 \mathrm{~g}$ for $22 \mathrm{~h}$ at $20^{\circ}$ in a Beckman L2-65 ultracentrifuge (Beckman, Montreal, Quebec, Canada). Lipoprotein fractions were assayed for lipids and protein as previously noted for whole plasma. Preliminary analysis of lipoprotein fractions for protein content indicated that the density ranges chosen for individual lipoprotein fractions allowed the recovery of equivalent fractions from plasma of birds fed on low-cholesterol and high-cholesterol diets (Fig. 1).

\section{Aortic cholesterol oxides}

Aortic tissue cholesterol oxides were determined by GCMS. Adhering tissue was removed from aortas before weighing and extraction of lipids according to the method of Folch et al. (1957). An internal standard, $5 \alpha$-cholestane, was added to samples before lipid extraction. Lipid extracts were evaporated to dryness with $\mathrm{N}_{2}$ and saponified with $1 \mathrm{M}-\mathrm{KOH}$ (in $\mathrm{CH}_{3} \mathrm{OH}$ ) overnight at room temperature. The saponified samples were extracted with diethyl ether, followed by washing with $0.5 \mathrm{M}-\mathrm{KOH}$ and distilled deionized water. The non-saponifiable material was then dried (anhydrous $\mathrm{Na}_{2} \mathrm{SO}_{4}$ ) before reduction of sample volume using $\mathrm{N}_{2}$, and transferred to sample vials (Pierce Chemical Co., Rockford, IL, USA). Samples were dried

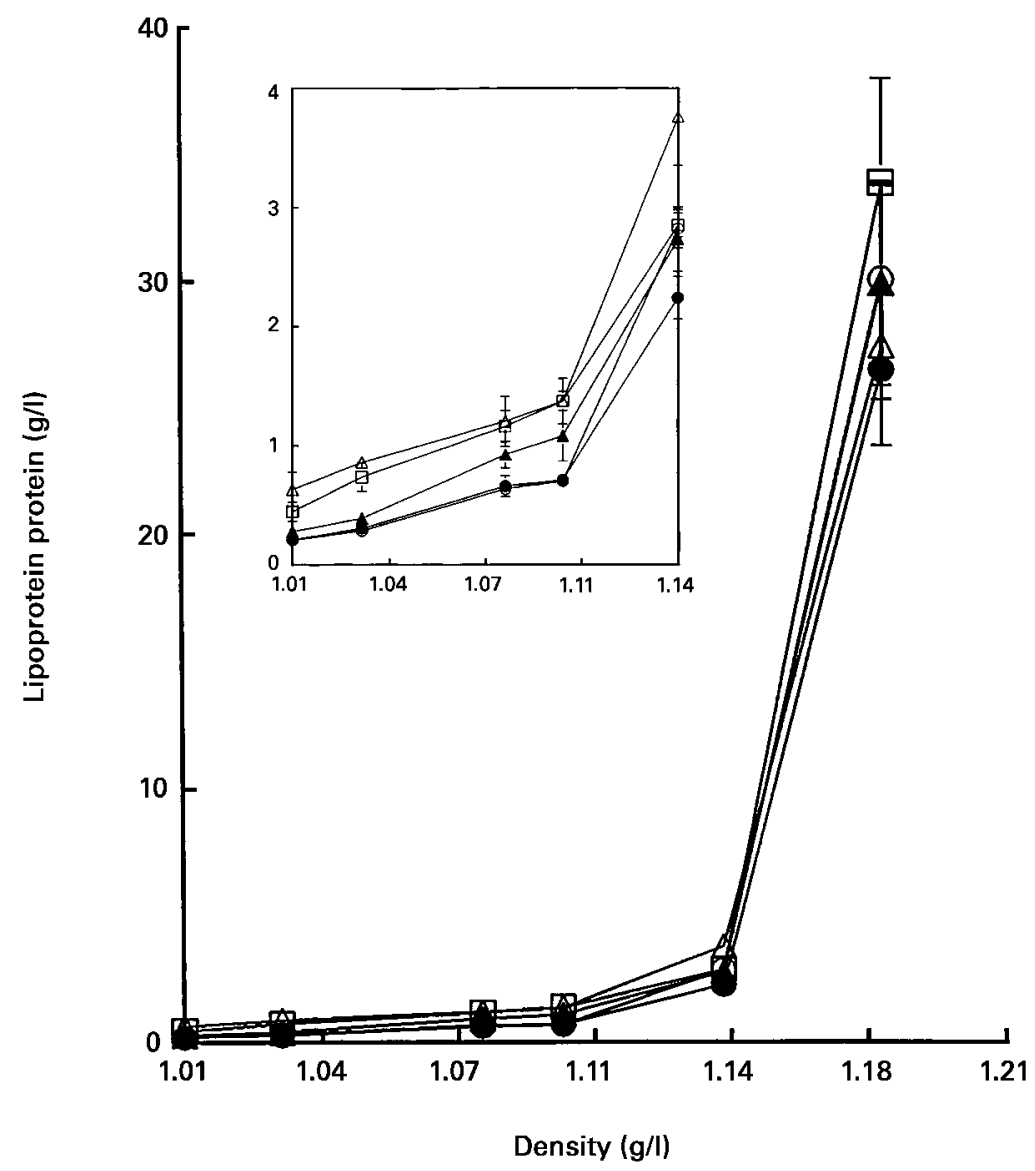

Fig. 1. Cumulative protein profiles of lipoprotein fractions recovered from plasma of atherosclerosis-susceptible Japanese quail fed on either a reference Turkey Starter diet alone (TS; diet A) or the TS diet supplemented with a low $(0.5 \mathrm{~g} / \mathrm{kg}$ diet $)$ or high $(5.0 \mathrm{~g} / \mathrm{kg}$ diet) level of cholesterol (diets $B$ and $\mathrm{C}$ ) or the TS diet supplemented with additional beef tallow $(66 \mathrm{~g} / \mathrm{kg}$ diet) and a low $(0.5 \mathrm{~g} / \mathrm{kg}$ diet) or high $(5.0 \mathrm{~g} / \mathrm{kg}$ diet) level of cholesterol (diets $D$ and $E)$. (O), Diet A; $(\bullet)$, diet $B ;(\triangle)$, diet $C ;(\boldsymbol{\Lambda})$, diet $D ;(\square)$, diet $E$. 
under vacuum before solubilization in dry pyridine. Solubilized samples were derivatized (Sylon BTZ; Supelco Inc., Oakville, ON, Canada) at room temperature for $30 \mathrm{~min}$. Derivatized standards (trivial name): cholest-3,5-dien-7one, cholest-5-en-3 $\beta$-ol (cholesterol), cholest-5-ene-3 $\beta$, $4 \beta$-diol ( $4 \beta$-hydroxycholesterol), cholest-5-ene-3 $\beta, 7 \alpha$-diol (7 $\alpha$-hydroxycholesterol), cholest-5-ene-3 $\beta, 7 \beta$-diol $(7 \beta$ hydroxycholesterol), cholest-5ene-3 $\beta, 25$-diol (25-hydroxycholesterol), 5,6 $\alpha$-epoxy-5 $\alpha$-cholestan-3 $\beta$-ol (cholesterol $5 \alpha, 6 \alpha$-epoxide), $5 \alpha$-cholestan- $3 \beta, 5,6 \beta$-triol (cholestanetriol), and $3 \beta$-hydroxycholest-5-ene-7-one (7-ketocholesterol; Steraloids Inc., Wilton, NH, USA) with internal standard, and samples, were analysed using a Carlo Erba GC (Carlo Erba Strumentazione, Italy) equipped with a flame ionization detector (GC-FID), and a DB-1 capillary column $(15 \mathrm{~m} \times 0.25 \mathrm{~mm}$ i.d., $0.1 \mu \mathrm{m}$ film thickness; J \& W Scientific Inc., Folsom, CA, USA). The carrier gas used was He with $\mathrm{N}_{2}$ as the make-up gas. The injector and detector temperatures were $250^{\circ}$ and $280^{\circ}$ respectively, while the oven temperature was programmed from $180^{\circ}$ to $250^{\circ}$ at the rate of $3 \% \mathrm{~min}$. The identity of the cholesterol oxides was confirmed with a Kratos MS80 mass spectrometer (Ramsey, NJ, USA) coupled to a Carlo Erba GC. Cholesterol oxides were quantified after confirmation of the response linearity of each derivatized sterol.

\section{Statistics}

All data are expressed as means with their standard errors. One-way ANOVA (SPSS for Windows, SPSS Inc., Chicago, IL, USA) was used to test for differences between experimental treatments. Where differences did exist, the source of the differences at a $P \leq 0 \cdot 05$ significance level was identified by the Student-Newman-Keuls multiple range test (SPSS). Two-way multiple ANOVA (MANOVA; SPSS) was used to identify any interactions between level of dietary fat and cholesterol level. Linear regression analyses (SPSS) were also performed.

\section{Results}

Animal growth, liver weights and lipid composition

There was no significant difference in body weight gain between quail fed on the two levels of dietary fat. Final body weights of quail were not affected by levels of dietary fat or cholesterol intake (mean 135 (SE 2) g). Liver tissue weights from birds fed on $\mathrm{HC}$ diets (diets $\mathrm{C}$ and $\mathrm{E}$ ) were significantly greater $(P<0.001)$ than livers from birds fed on low cholesterol (LC) diets (diets B and D) or the reference TS diet (diet A; Table 3). Also, livers collected from birds fed on $\mathrm{HC}$ diets (diets $\mathrm{C}$ and $\mathrm{E}$ ) were pale coloured in comparison with livers from animals fed on diets A, B and D. A significant interaction was recorded between dietary fat and dietary cholesterol levels with liver weight $(P=0 \cdot 007)$, as demonstrated by the greater liver tissue weights of birds fed on diet E. Quail fed on the HC diets (C and E) had greater amounts of liver cholesterol $(P=0 \cdot 001)$ compared with those fed on LC diets, as expected (Table 3). However, hepatic cholesterol content was not influenced by variations in the level of dietary fat. The TG content of livers was significantly increased $(P=0 \cdot 01)$ in quail fed on diets containing the higher level of beef tallow (diets D and E). However, dietary cholesterol level did not have any effect on liver TG content (Table 3).

\section{Plasma composition of quail fed on reference and experimental diets}

Birds fed on the reference TS diet (diet A) exhibited similar plasma TC, TG, PL and protein levels as counterparts fed on LC diets (diets B and D; Table 4). As expected, significantly greater levels of plasma TC $(P<0 \cdot 001)$ were observed in birds fed on the $\mathrm{HC}$ diets (C and $\mathrm{E})$. Birds fed on the $\mathrm{HC}$ diets also exhibited significant elevations in TG $(P<0 \cdot 001)$ and PL $(P<0.001)$ compared with birds fed on LC diets (B and D) as well as the reference diet A. A significant interaction $(P=0.05)$ between dietary fat level and cholesterol intake was observed only with plasma TG. There was no effect of dietary fat level or cholesterol intake on plasma protein content.

Birds fed on the $\mathrm{HC}$ diets (diets $\mathrm{C}$ and $\mathrm{E}$ ) exhibited a thick layer of lipid at $\rho_{20}<1.006$ on ultracentrifugation, which represented the absorptive portomicron fraction and contained large amounts of cholesterol, TG and PL (Tables 57). This lipoprotein fraction was undetectable in plasma

Table 3. Liver tissue weights and lipid composition in atherosclerosis-susceptible Japanese quail fed on experimental diets

(Values are means with standard errors for twelve quail)

\begin{tabular}{|c|c|c|c|c|c|c|c|c|}
\hline & \multirow[b]{3}{*}{$\begin{array}{l}\text { Mean } \\
\text { SE }\end{array}$} & \multicolumn{5}{|c|}{ Diets* $^{*}$} & \multirow{2}{*}{\multicolumn{2}{|c|}{$\begin{array}{c}\text { ANOVA } \\
P \text { value }\end{array}$}} \\
\hline & & A & $\mathrm{B}$ & $\mathrm{C}$ & $\mathrm{D}$ & $E$ & & \\
\hline Liver wt (g/kg body wt) & & $\begin{array}{r}15 \\
1\end{array}$ & $\begin{array}{r}17 \\
1\end{array}$ & $\begin{array}{r}22 \\
1\end{array}$ & $\begin{array}{r}17 \\
1\end{array}$ & $\begin{array}{r}28 \\
2\end{array}$ & $\begin{array}{l}C \\
L \\
C \times L\end{array}$ & $\begin{array}{r}<0.001 \\
0.002 \\
0.007\end{array}$ \\
\hline Liver cholesterol (mmol/mg tissue wet wt) & $\begin{array}{l}\text { Mean } \\
\text { SE }\end{array}$ & $\begin{array}{r}16 \\
3\end{array}$ & $\begin{array}{r}13 \\
1\end{array}$ & $\begin{array}{r}30 \\
2\end{array}$ & $\begin{array}{r}14 \\
2\end{array}$ & $\begin{array}{r}33 \\
2\end{array}$ & $\begin{array}{l}C \\
L \\
C \times L\end{array}$ & $\begin{array}{l}0.001 \\
\text { NS } \\
\text { NS }\end{array}$ \\
\hline Liver triacylglycerol (mmol/mg tissue wet wt) & $\begin{array}{l}\text { Mean } \\
\text { SE }\end{array}$ & $\begin{array}{r}31 \\
3\end{array}$ & $\begin{array}{r}22 \\
1\end{array}$ & $\begin{array}{r}23 \\
3\end{array}$ & $\begin{array}{r}29 \\
2\end{array}$ & $\begin{array}{r}35 \\
4\end{array}$ & $\begin{array}{l}\mathrm{C} \\
\mathrm{L} \\
\mathrm{C} \times \mathrm{L}\end{array}$ & $\begin{array}{c}\text { NS } \\
0.01 \\
\text { NS }\end{array}$ \\
\hline
\end{tabular}

${ }^{*}$ For details of diets, see Tables 1 and 2

†C, cholesterol treatment effect; L, fat level treatment effect; $\mathrm{C} \times \mathrm{L}$, cholesterol $\times$ fat level treatment interaction by two-way ANOVA. 
Table 4. Whole plasma lipid and protein concentrations in atherosclerosis-susceptible Japanese quail fed on experimental diets

(Values are means with their standard errors for twelve quail)

\begin{tabular}{|c|c|c|c|c|c|c|c|c|}
\hline \multirow[b]{2}{*}{ Plasma component } & & \multicolumn{5}{|c|}{ Diets $^{*}$} & \multirow{2}{*}{\multicolumn{2}{|c|}{$\begin{array}{l}\text { ANOVA } \\
P \text { value } \dagger\end{array}$}} \\
\hline & & $A$ & $\mathrm{~B}$ & C & $\mathrm{D}$ & $E$ & & \\
\hline Total cholesterol $(\mathrm{mmol} / \mathrm{l})$ & $\begin{array}{l}\text { Mean } \\
\text { SE }\end{array}$ & $\begin{array}{l}5 \cdot 33 \\
0.32\end{array}$ & $\begin{array}{l}7 \cdot 06 \\
0 \cdot 38\end{array}$ & $\begin{array}{r}36 \cdot 8 \\
4 \cdot 9\end{array}$ & $\begin{array}{l}7 \cdot 75 \\
0.36\end{array}$ & $\begin{array}{r}43.4 \\
3.5\end{array}$ & $\begin{array}{l}\mathrm{C} \\
\mathrm{L} \\
\mathrm{C} \times \mathrm{L}\end{array}$ & $\begin{array}{c}<0 \cdot 001 \\
N S \\
N S\end{array}$ \\
\hline Triacylglycerol (mmol/l) & $\begin{array}{l}\text { Mean } \\
\text { SE }\end{array}$ & $\begin{array}{l}1 \cdot 89 \\
0 \cdot 19\end{array}$ & $\begin{array}{l}3.57 \\
0.76\end{array}$ & $\begin{array}{l}7 \cdot 81 \\
1.51\end{array}$ & $\begin{array}{l}2.73 \\
0.38\end{array}$ & $\begin{array}{r}11 \cdot 8 \\
1 \cdot 8\end{array}$ & $\begin{array}{l}\mathrm{C} \\
\mathrm{L} \\
\mathrm{C} \times \mathrm{L}\end{array}$ & $\begin{array}{c}<0.001 \\
\text { NS } \\
0.05\end{array}$ \\
\hline Phospholipids (mmol/l) & $\begin{array}{l}\text { Mean } \\
\text { SE }\end{array}$ & $\begin{array}{l}4.95 \\
0.36\end{array}$ & $\begin{array}{l}5.02 \\
0.32\end{array}$ & $\begin{array}{r}15 \cdot 7 \\
2 \cdot 1\end{array}$ & $\begin{array}{l}5 \cdot 19 \\
0.32\end{array}$ & $\begin{array}{r}20 \cdot 7 \\
2 \cdot 4\end{array}$ & $\begin{array}{l}\mathrm{C} \\
\mathrm{L} \\
\mathrm{C} \times \mathrm{L}\end{array}$ & $\begin{array}{c}<0.01 \\
\text { NS } \\
\text { NS }\end{array}$ \\
\hline Protein $(\mathrm{g} / \mathrm{l})$ & $\begin{array}{l}\text { Mean } \\
\text { SE }\end{array}$ & $\begin{array}{r}33 \cdot 1 \\
2 \cdot 7\end{array}$ & $\begin{array}{r}32 \cdot 6 \\
4 \cdot 0\end{array}$ & $\begin{array}{r}37 \cdot 8 \\
3 \cdot 6\end{array}$ & $\begin{array}{r}31 \cdot 4 \\
4 \cdot 3\end{array}$ & $\begin{array}{r}38 \cdot 9 \\
3.1\end{array}$ & $\begin{array}{l}C \\
L \\
C \times L\end{array}$ & $\begin{array}{l}\text { NS } \\
\text { NS } \\
\text { NS }\end{array}$ \\
\hline
\end{tabular}

* For details of diets, see Tables 1 and 2.

†C, cholesterol treatment effect; L, fat level treatment effect; $\mathrm{C} \times \mathrm{L}$, cholesterol $\times$ fat level treatment interaction by two-way ANOVA.

samples collected from quail fed on the LC diets (A, B and D). The TG and PL contents of the portomicron fraction of plasma collected from birds fed on diet $\mathrm{C}$ were significantly lower $(P<0.05)$ than those of birds fed on diet E. When whole plasma from experimental quail was ultracentrifuged, five lipoprotein fractions were isolated corresponding to VLDL (fraction 1), LDL (fraction 2), a lower-density HDL subclass, analogous to $\mathrm{HDL}_{2}$ (fraction 3 ), a higher-density HDL subclass, analogous to $\mathrm{HDL}_{3}$ (fraction 4) and lastly, very-high-density lipoprotein (fraction 5). The level of dietary fat fed to birds had no effect on lipoprotein TC content (Table 5). However, the TC content of lipoprotein fractions 1,2 and 3 was enhanced $(P<0.05)$ in birds fed on $\mathrm{HC}$ diets (C and $\mathrm{E})$ compared with birds fed on LC diets (A,
$\mathrm{B}$ and D). The TC contents of lipoprotein fractions 4 and 5 were not affected by dietary treatment. Whole plasma TC content was positively correlated with hepatic tissue TC content $(r 0 \cdot 839, P<0 \cdot 001)$ and positive correlations were also observed between hepatic tissue TC content and TC levels of lipoprotein fractions $1(r \quad 0 \cdot 819, P<0 \cdot 001), 2$ $(r 0.765, P<0.001)$ and $3(r 0.747, P<0.001)$. Whole plasma TG content was positively correlated with hepatic tissue TC content $(r 0.581, P=0 \cdot 002)$, but was not related to hepatic tissue TG content.

Dietary fat level did not have a significant effect on either lipoprotein TG or PL contents (Tables 6 and 7). However, the TG and PL contents of lipoprotein fractions 1 and 2 were significantly greater $(P<0 \cdot 05)$ in quail fed

Table 5. Plasma lipoprotein cholesterol concentrations in atherosclerosis-susceptible Japanese quail fed on experimental diets

(Values are means with their standard errors for twelve quail)

\begin{tabular}{|c|c|c|c|c|c|c|}
\hline \multirow[b]{2}{*}{ Plasma fraction $†$} & & \multicolumn{5}{|c|}{ Diets* $^{*}$} \\
\hline & & $A$ & $\mathrm{~B}$ & $\mathrm{C}$ & $\mathrm{D}$ & E \\
\hline Portomicron-cholesterol (mmol/l) & $\begin{array}{l}\text { Mean } \\
\text { SE }\end{array}$ & - & - & $\begin{array}{c}12 \cdot 6^{\mathrm{a}} \\
4 \cdot 1\end{array}$ & - & $\begin{array}{c}14 \cdot 3^{\mathrm{a}} \\
3 \cdot 7\end{array}$ \\
\hline Fraction 1-cholesterol (mmol/l) & $\begin{array}{l}\text { Mean } \\
\text { SE }\end{array}$ & $\begin{array}{l}0.29^{a} \\
0.06\end{array}$ & $\begin{array}{l}1.94^{b} \\
0.14\end{array}$ & $\begin{array}{c}13 \cdot 0^{\mathrm{C}} \\
2 \cdot 2\end{array}$ & $\begin{array}{l}1 \cdot 89^{b} \\
0 \cdot 14\end{array}$ & $\begin{array}{c}15 \cdot 1^{\mathrm{c}} \\
2 \cdot 0^{-}\end{array}$ \\
\hline Fraction 2-cholesterol (mmol/l) & $\begin{array}{l}\text { Mean } \\
\text { SE }\end{array}$ & $\begin{array}{l}0.50^{a} \\
0.10\end{array}$ & $\begin{array}{l}0.84^{a} \\
0.06\end{array}$ & $\begin{array}{l}3.34^{b} \\
0.98\end{array}$ & $\begin{array}{l}0.94^{a} \\
0.07\end{array}$ & $\begin{array}{l}4.90^{b} \\
0.53\end{array}$ \\
\hline Fraction 3-cholesterol (mmol/l) & $\begin{array}{l}\text { Mean } \\
\text { SE }\end{array}$ & $\begin{array}{l}0.65^{\mathrm{a}} \\
0.04\end{array}$ & $\begin{array}{l}0.76^{a} \\
0 \cdot 19\end{array}$ & $\begin{array}{l}1 \cdot 75^{b} \\
0.53\end{array}$ & $\begin{array}{l}1 \cdot 13^{\mathrm{ab}} \\
0 \cdot 10\end{array}$ & $\begin{array}{l}1.93^{b} \\
0.24\end{array}$ \\
\hline Fraction 4-cholesterol (mmol/l) & $\begin{array}{l}\text { Mean } \\
\text { SE }\end{array}$ & $\begin{array}{l}2 \cdot 44^{\mathrm{a}} \\
0 \cdot 16\end{array}$ & $\begin{array}{l}2 \cdot 51^{\mathrm{a}} \\
0 \cdot 11\end{array}$ & $\begin{array}{l}3 \cdot 01^{a} \\
0 \cdot 34\end{array}$ & $\begin{array}{l}2 \cdot 85^{\mathrm{a}} \\
0 \cdot 19\end{array}$ & $\begin{array}{l}2.92^{2} \\
0.37\end{array}$ \\
\hline Fraction 5-cholesterol (mmol/l) & $\begin{array}{l}\text { Mean } \\
\text { SE }\end{array}$ & $\begin{array}{l}0.28^{a} \\
0.03\end{array}$ & $\begin{array}{l}0.38^{a} \\
0.04\end{array}$ & $\begin{array}{l}0.33^{a} \\
0.09\end{array}$ & $\begin{array}{l}0.41^{a} \\
0.09\end{array}$ & $\begin{array}{l}0.43^{\circ} \\
0.13\end{array}$ \\
\hline
\end{tabular}

a,b,c Mean values within a row not sharing a common superscript letter were significantly different, $P \leq 0.05$.

* For details of diets, see Tables 1 and 2 .

†Fraction numbers refer to position in density gradient: portomicron, $\rho_{20}<1.006$; fraction $1,1.006<\rho_{20}<1.020$; fraction 2, $1.030<\rho_{20}<1.046$; fraction $3,1.050<\rho_{20}<1.080$; fraction $4,1.106<\rho_{20}<1.184$; fraction 5 , $\rho_{20}>1.21$. For details, see p. 92. 
Table 6. Plasma lipoprotein triacylglycerol (TG) concentrations in atherosclerosissusceptible Japanese quail fed on experimental diets

(Values are means with their standard errors for twelve quail)

\begin{tabular}{lllllll}
\hline & & \multicolumn{5}{c}{ Diets $^{*}$} \\
\cline { 3 - 7 } Plasma fraction† & & A & B & C & D & E \\
\hline Portomicron-TG (mmol/l) & Mean & - & - & $2 \cdot 89^{\mathrm{a}}$ & - & $5.78^{\mathrm{b}}$ \\
& SE & & & 0.76 & & 0.93 \\
Fraction 1-TG (mmol/l) & Mean & $0.32^{\mathrm{a}}$ & $1.14^{\mathrm{a}}$ & $2.76^{\mathrm{b}}$ & $0.99^{\mathrm{a}}$ & $2.91^{\mathrm{b}}$ \\
& SE & 0.04 & 0.22 & 0.78 & 0.26 & 0.77 \\
Fraction 2-TG (mmol/l) & Mean & $0.14^{\mathrm{a}}$ & $0.28^{\mathrm{a}}$ & $0.53^{\mathrm{b}}$ & $0.26^{\mathrm{a}}$ & $0.50^{\mathrm{b}}$ \\
& SE & 0.03 & 0.02 & 0.11 & 0.03 & 0.11 \\
Fraction 3-TG (mmol/l) & Mean & $0.16^{\mathrm{a}}$ & $0.29^{\mathrm{a}}$ & $0.28^{\mathrm{a}}$ & $0.25^{\mathrm{a}}$ & $0.35^{\mathrm{a}}$ \\
& SE & 0.01 & 0.06 & 0.09 & 0.04 & 0.04 \\
Fraction 4-TG (mmol/l) & Mean & $0.61^{\mathrm{a}}$ & $0.89^{\mathrm{a}}$ & $0.51^{\mathrm{a}}$ & $0.65^{\mathrm{a}}$ & $0.75^{\mathrm{a}}$ \\
& SE & 0.02 & 0.08 & 0.08 & 0.07 & 0.08 \\
Fraction 5-TG (mmol/l) & Mean & $0.52^{\mathrm{a}}$ & $0.62^{\mathrm{a}}$ & $0.41^{\mathrm{a}}$ & $0.52^{\mathrm{a}}$ & $0.57^{\mathrm{a}}$ \\
& SE & 0.04 & 0.05 & 0.06 & 0.05 & 0.06 \\
\hline
\end{tabular}

${ }^{a, b}$ Mean values within a row not sharing a common superscript letter were significantly different, $P \leqslant 0.05$.

* For details of diets, see Tables 1 and 2.

† For details of plasma fractions, see Table 5 .

on $\mathrm{HC}$ diets $(\mathrm{C}$ and $\mathrm{E})$ when compared with those fed on LC diets (A, B and D). Dietary treatment did not influence either the TG or PL content of lipoprotein fractions 3, 4 or 5 .

\section{Aortic plaque score and percentage area covered}

Birds fed on either the TS reference $\operatorname{diet}(\operatorname{diet} \mathrm{A})$ or the LC diets (diets B and D) did not exhibit detectable aortic plaque (Fig. 2(a)). On the other hand, feeding quail on HC diets $(\mathrm{C}$ and $\mathrm{E})$ resulted in significant aortic plaque development $(P<0 \cdot 001)$. The severity of aortic plaque formation in animals fed on the latter diets was enhanced in quail fed on diet $\mathrm{E}$ compared with birds fed on diet $\mathrm{C}$, as demonstrated by the significant interaction recorded $(P=0 \cdot 02)$. The percentage of aortic lumen covered by plaque from birds fed on diet $\mathrm{E}$ was greater than in counterparts fed on diet $\mathrm{C}$, as demonstrated by the interaction recorded between dietary fat and cholesterol levels $(P=0 \cdot 003$; Fig. 2(b)). Aortic tissue plaque score was positively correlated with plasma TC $(r 0.624, P<0.001)$ as well as the cholesterol content of lipoprotein fractions $1(r 0.560, P=0.004) ; 2$ $(r 0.669, P<0.001) ; 3(r 0.784, P<0.001)$ and $4(r 0.508$, $P=0 \cdot 011)$. Similarly, the percentage of aortic tissue area

Table 7. Plasma lipoprotein phospholipid $(\mathrm{PL})$ concentrations in atherosclerosissusceptible Japanese quail fed on experimental diets

(Values are means with their standard errors for twelve quail)

\begin{tabular}{|c|c|c|c|c|c|c|}
\hline \multirow[b]{2}{*}{ Plasma fraction† } & & \multicolumn{5}{|c|}{ Diets* } \\
\hline & & A & B & $\mathrm{C}$ & $\mathrm{D}$ & $E$ \\
\hline Portomicron-PL (mmol/l) & $\begin{array}{l}\text { Mean } \\
\text { SE }\end{array}$ & - & - & $\begin{array}{l}7.56^{a} \\
0.52\end{array}$ & - & $\begin{array}{c}11 \cdot 1^{\mathrm{b}} \\
0.9\end{array}$ \\
\hline Fraction 1-PL (mmol/l) & $\begin{array}{l}\text { Mean } \\
\text { SE }\end{array}$ & $\begin{array}{l}0.35^{a} \\
0.03\end{array}$ & $\begin{array}{l}0.53^{\mathrm{a}} \\
0.08\end{array}$ & $\begin{array}{l}2 \cdot 70^{b} \\
0.70\end{array}$ & $\begin{array}{l}0.69^{a} \\
0.12\end{array}$ & $\begin{array}{l}4 \cdot 28^{b} \\
0.84\end{array}$ \\
\hline Fraction 2-PL (mmol/l) & $\begin{array}{l}\text { Mean } \\
\text { SE }\end{array}$ & $\begin{array}{l}0.29^{a} \\
0.02\end{array}$ & $\begin{array}{l}0.12^{\mathrm{a}} \\
0.02\end{array}$ & $\begin{array}{l}1.06^{b} \\
0.36\end{array}$ & $\begin{array}{l}0.14^{a} \\
0.01\end{array}$ & $\begin{array}{l}1 \cdot 16^{b} \\
0.14\end{array}$ \\
\hline Fraction 3-PL (mmol/l) & $\begin{array}{l}\text { Mean } \\
\text { SE }\end{array}$ & $\begin{array}{l}0 \cdot 83^{a} \\
0 \cdot 10\end{array}$ & $\begin{array}{l}0.64^{b} \\
0 \cdot 14\end{array}$ & $\begin{array}{l}0 \cdot 72^{\mathrm{a}} \\
0 \cdot 15\end{array}$ & $\begin{array}{l}0.97^{\mathrm{a}} \\
0.17\end{array}$ & $\begin{array}{l}0.97^{\circ} \\
0.08\end{array}$ \\
\hline Fraction 4-PL (mmol/l) & $\begin{array}{l}\text { Mean } \\
\text { SE }\end{array}$ & $\begin{array}{l}2 \cdot 44^{\mathrm{a}} \\
0 \cdot 17\end{array}$ & $\begin{array}{l}2 \cdot 84^{\mathrm{a}} \\
0 \cdot 14\end{array}$ & $\begin{array}{l}2 \cdot 11^{\mathrm{a}} \\
0 \cdot 26\end{array}$ & $\begin{array}{l}2 \cdot 74^{\mathrm{a}} \\
0 \cdot 11\end{array}$ & $\begin{array}{l}1.93^{\mathrm{a}} \\
0.30\end{array}$ \\
\hline Fraction 5-PL (mmol/l) & $\begin{array}{l}\text { Mean } \\
\text { SE }\end{array}$ & $\begin{array}{l}0.64^{a} \\
0.06\end{array}$ & $\begin{array}{l}0.43^{\mathrm{a}} \\
0.05\end{array}$ & $\begin{array}{l}0.40^{\mathrm{a}} \\
0.06\end{array}$ & $\begin{array}{l}0.39^{a} \\
0.03\end{array}$ & $\begin{array}{l}0.35^{2} \\
0.04\end{array}$ \\
\hline
\end{tabular}

${ }^{a, b}$ Mean values within a row not sharing a common superscript letter were significantly different, $P \leqslant 0.05$.

* For details of diets, see Tables 1 and 2.

†For details of plasma fractions, see Table 5. 
covered by plaque was positively related to plasma TC $(r 0.578, P<0.001)$ as well as the cholesterol content of lipoprotein fractions 1 to 3 . It is noteworthy that positive, albeit weak, correlations were also recorded between whole plasma TG concentrations and aortic tissue plaque score $(r 0.412, P=0.001)$ and percentage of aortic tissue area covered by plaque $(r 0.390, P=0 \cdot 001)$.

\section{Aortic cholesterol and cholesterol oxide content}

Aortas from birds fed on the reference TS $\operatorname{diet}(\operatorname{diet} \mathrm{A})$ and the LC diets (diets B and D) were devoid of any detectable plaque on the luminal surface and exhibited low levels of cholesterol (Table 8). In all cases, the combination of the low level of tissue cholesterol and the absence of cholesterol
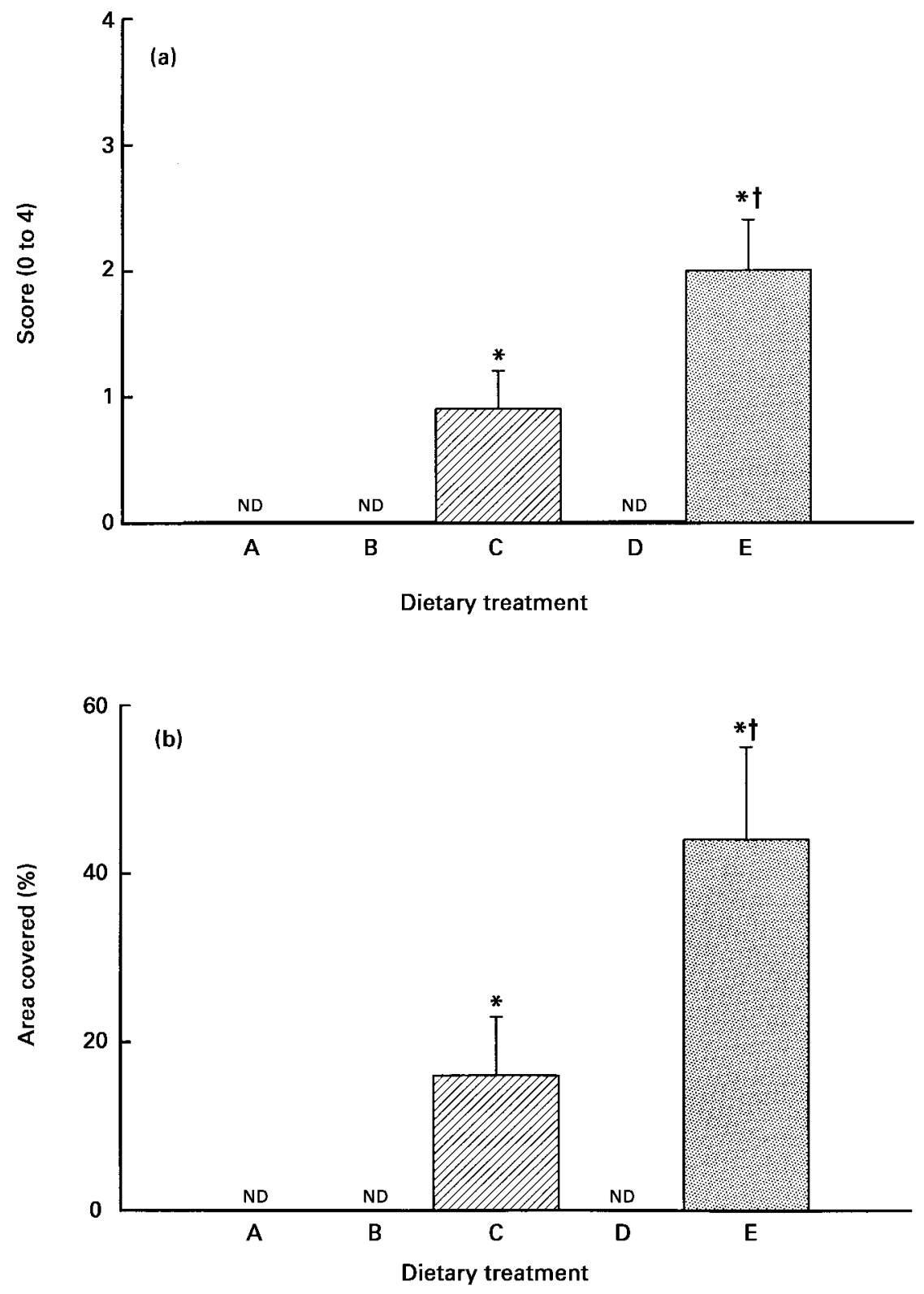

Fig. 2. (a) Aortic plaque score and (b) percentage area covered by plaque from atherosclerosis-susceptible Japanese quail fed on either a reference Turkey Starter diet alone (TS; diet A) or the TS diet supplemented with a low $(0.5 \mathrm{~g} / \mathrm{kg}$ diet $)$ or high $(5.0 \mathrm{~g} / \mathrm{kg}$ diet) level of cholesterol (diets B and C) or the TS diet supplemented with additional beef tallow $(66 \mathrm{~g} / \mathrm{kg}$ diet) and a low $(0.5 \mathrm{~g} / \mathrm{kg}$ diet) or high $(5.0 \mathrm{~g} / \mathrm{kg}$ diet) level of cholesterol (diets $D$ and $E)$. Plaque score based on scale of 0 (not detected (ND)) =clean surface; $1=\leq 5$ plaques, $2=6-20$ plaques; $3=>20$ plaques; $4=$ massive atheromas seen. Values represent the mean of two judges evaluating in a double-blind protocol. Area covered (\%) is the percentage of aortic epithelium covered by plaque, range 0 (ND) $-100 \%$. Panel (a): * significant dietary cholesterol level effect $(P<0.001)$; † significant interaction between cholesterol and dietary fat level $(P=0.02)$. Panel $(\mathrm{b})$ : * significant dietary cholesterol level effect $(P<0.001)$; † significant interaction between cholesterol and dietary fat level $(P=0.03)$. 
Table 8. Gas-chromatography-mass spectroscopic quantitation of cholesterol and cholesterol oxide content of aortic tissue from atherosclerosis-susceptible Japanese quail fed on experimental diets

\begin{tabular}{|c|c|c|c|c|c|c|c|}
\hline \multirow[b]{2}{*}{ Dietary treatment* } & \multirow[b]{2}{*}{ Plaque score $†$} & \multicolumn{6}{|c|}{ Cholesterol and cholesterol oxides (mg/g tissue) } \\
\hline & & Cholesterol & $5,6 \alpha$-epoxide & $7 \beta-\mathrm{OH}$ & triol & 7-keto & $25-\mathrm{OH}$ \\
\hline $\begin{array}{l}\text { A } \\
A\end{array}$ & $\begin{array}{l}0 / 0 / 0 \\
0 / 0 / 0\end{array}$ & $\begin{array}{l}0.89 \\
0.68\end{array}$ & $\begin{array}{l}\text { ND } \\
\text { ND }\end{array}$ & $\begin{array}{l}\text { ND } \\
\text { ND }\end{array}$ & $\begin{array}{l}\text { ND } \\
\text { ND }\end{array}$ & $\begin{array}{l}\text { ND } \\
\text { ND }\end{array}$ & $\begin{array}{l}\text { ND } \\
\text { ND }\end{array}$ \\
\hline $\begin{array}{l}\text { B } \\
\text { B }\end{array}$ & $\begin{array}{l}0 / 0 / 0 \\
0 / 0 / 0\end{array}$ & $\begin{array}{l}0.76 \\
0.63\end{array}$ & $\begin{array}{l}\text { ND } \\
\text { ND }\end{array}$ & $\begin{array}{l}\text { ND } \\
\text { ND }\end{array}$ & $\begin{array}{l}\text { ND } \\
\text { ND }\end{array}$ & $\begin{array}{l}\text { ND } \\
\text { ND }\end{array}$ & $\begin{array}{l}\text { ND } \\
\text { ND }\end{array}$ \\
\hline $\begin{array}{l}C \\
C \\
C \\
C\end{array}$ & $\begin{array}{l}0 / 0 / 0 \\
0 / 2 / 0 \\
2 / 1 / 2 \\
3 / 3 / 4\end{array}$ & $\begin{array}{l}1.24 \\
1.69 \\
5.60 \\
4.99\end{array}$ & $\begin{array}{c}\text { ND } \\
\text { ND } \\
0 \cdot 17 \\
1 \cdot 33\end{array}$ & $\begin{array}{l}\text { ND } \\
\text { ND } \\
\text { ND } \\
\text { ND }\end{array}$ & $\begin{array}{l}\text { ND } \\
\text { ND } \\
\text { ND } \\
\text { ND }\end{array}$ & $\begin{array}{l}\text { ND } \\
\text { ND } \\
\text { ND } \\
\text { ND }\end{array}$ & $\begin{array}{l}\text { ND } \\
\text { ND } \\
\text { ND } \\
\text { ND }\end{array}$ \\
\hline $\begin{array}{l}D \\
D\end{array}$ & $\begin{array}{l}0 / 0 / 0 \\
0 / 0 / 0\end{array}$ & $\begin{array}{l}2 \cdot 46 \\
2 \cdot 31\end{array}$ & $\begin{array}{l}\text { ND } \\
\text { ND }\end{array}$ & $\begin{array}{l}\text { ND } \\
\text { ND }\end{array}$ & $\begin{array}{l}\text { ND } \\
\text { ND }\end{array}$ & $\begin{array}{l}\text { ND } \\
\text { ND }\end{array}$ & $\begin{array}{l}\text { ND } \\
\text { ND }\end{array}$ \\
\hline $\begin{array}{l}\mathrm{E} \\
\mathrm{E}\end{array}$ & $\begin{array}{l}3 / 2 / 1 \\
4 / 4 / 4\end{array}$ & $\begin{array}{l}12 \cdot 63 \\
21.62\end{array}$ & $\begin{array}{l}0 \cdot 19 \\
0.21\end{array}$ & $\begin{array}{l}0.59 \\
0.99\end{array}$ & $\begin{array}{l}0.15 \\
0.30\end{array}$ & $\begin{array}{l}0 \cdot 13 \\
0.08\end{array}$ & $\begin{array}{c}N D \\
0.38\end{array}$ \\
\hline
\end{tabular}

oxides in aortic tissue of quail fed on diets A, B and D were associated with an absence of aortic plaque deposition. The aortas from quail fed on diet $\mathrm{C}$ contained approximately twice the amount of cholesterol compared with birds fed on diets $\mathrm{A}$ or $\mathrm{B}$, in addition to detectable levels of a single cholesterol oxide, 5,6 $\alpha$-epoxy- $5 \alpha$-cholesterol (Table 8). The higher level of beef tallow in combination with a high level of cholesterol in diet $\mathrm{E}$ was associated with the presence of greater cholesterol and several cholesterol oxides, including 5,6 $\alpha$-epoxy-5 $\alpha$-cholesterol, $7 \beta$-hydroxycholesterol, cholestanetriol, 7-ketocholesterol and 25-hydroxycholesterol in aortic tissue from these animals.

\section{Discussion}

The present study describes the effects of feeding different levels of saturated fat and cholesterol on plasma and lipoprotein lipid profiles in relation to aortic tissue plaque deposition and associated cholesterol and oxysterol content in the atherosclerosis-susceptible Japanese quail. The choice of beef tallow used as the fat source in order to vary the energy content of experimental diets was based on observations of others, where feeding tallow produced an increased percentage of $14: 0$ and 16:0 and decreased $18: 2 n-6$ fatty acids, specifically in plasma relative to polyunsaturated fatty acid-based diets (Faidley et al. 1990). In addition to altering the energy content of our experimental diets, relative differences in the proportion of saturated and polyunsaturated fatty acids were also achieved (i.e. diets A, B and C, $18: 2 n-6 / 14: 0$ value of $12 \cdot 1-13 \cdot 3$ v. 6.8 for diets $\mathrm{D}$ and $\mathrm{E})$ by supplementing diets with beef tallow.

\section{Validation of quail animal model}

The severe aortic plaque deposition obtained in quail fed on the atherogenic diets containing $\mathrm{HC}$ and cholic acid over a relatively short period of 9 weeks is similar to the accelerated atherogenesis observed in the apo-E deficient mouse used to examine the effect of different dietary lipids on the development of aortic lesions (Nishina et al. 1993). Both elevated plasma TG levels as well as the presence of TG-rich lipoproteins have also been closely associated with coronary artery disease (Patsch et al. 1992). Our results using the quail model extend the findings of others by showing that the diet-induced elevations in plasma TC, TG and PL and milky appearance were primarily associated with the absorptive portomicron fraction. The direct extrapolation of results obtained in this quail model to the human situation requires caution however, due to species differences in lipoprotein metabolism.

\section{Plasma and hepatic tissue lipid response to dietary fat level}

The combination of increased levels of $14: 0$ and $16: 0$ with decreased $18: 2 n-6$ intake can further the development of hypercholesterolaemia and impaired lipoprotein metabolism in a number of animal models (Lindsey et al. 1990; Khosla \& Hayes, 1993; Hayes et al. 1995). In the present study it was clear that feeding quail on LC diets supplemented with beef tallow and containing a greater proportion of energy from fat as well as a low $\mathrm{P}: \mathrm{S}$ ratio was not sufficient to influence plasma lipid profiles or hepatic cholesterol content in quail. This observation could be specific to the choice of beef tallow used in this study since beef tallow is a good source of $18: 0$ and 18:1; two fatty acids that are not associated with a hypercholesterolaemic response relative to other saturated fats (Grundy \& Denke, 1991; Fernandez \& McNamara, 1994). In contrast, Fungwe et al. (1994) have reported an enhanced hepatic cholesterol synthesis and TG content in rats when dietary fat content increased from 5 to $20 \%$. However, unlike our long-term feeding study which used beef tallow to increase the fat content of diets fed to quail, Fungwe et al. (1994) fed maize oil, which contains a greater amount of $18: 2 n-6$, a similar amount of $18: 1$ and approximately one-seventh the 
18: 0 content to rats for only $7 \mathrm{~d}$. Taken together, these results demonstrate the importance of evaluating the specific fatty acid content of different fats in predicting speciesspecific changes in plasma and liver lipids, especially when cholesterol is absent or present at a very low level in the diet.

A different result was observed, however, in quail fed on tallow-supplemented diets containing high levels of cholesterol. The reduced $\mathrm{P}: \mathrm{S}$ ratio and increases in 14:0 and $16: 0$ saturated fatty acids, relative to $18: 2 n-6$ in diets fed to these birds, together with the higher intake of cholesterol produced dramatic hypercholesterolaemia that has been explained by others as involving an effect of cholesterol to amplify the impact of $14: 0$ and 16:0 in the absence of $18: 2 n-6$ (Khosla \& Hayes, 1993). Moreover, Mustad et al. (1996) have also shown that $18: 2 n-6$ feeding resulted in enhanced hepatic LDL-receptor protein and mRNA levels compared with 16:0 when pigs were fed on high-cholesterol diets.

\section{Effect of dietary cholesterol on plasma lipids}

Dietary cholesterol has been reported either to have a minimal effect on plasma TC (Keys et al. 1956), or to contribute significantly to elevations in plasma cholesterol (Lipid Research Clinics Program, 1984). The presence of increased cholesterol levels in the diet will elevate serum and aortic tissue cholesterol and increase aortic atherosclerosis in the atherosclerosis-susceptible pigeon (Clarkson et al. 1962). In the quail model, a wide range of cholesterol supplementation levels $(1 \cdot 0-20 \mathrm{~g} / \mathrm{kg})$ have been used to raise plasma cholesterol concentrations and vary the temporal development and severity of aortic plaque deposition similar to that reported with human atherosclerosis (Shih et al. 1983; Radcliffe \& Tramposch, 1988). A primary component of the hypercholesterolaemia in quail fed on $\mathrm{HC}$ diets was the prominent lipid-rich portomicron fraction observed in plasma collected from these birds, but not detected in counterparts fed on LC diets. Moreover, our results also associate diet-induced increases in plasma cholesterol with increases in VLDL- (fraction 1), LDL(fraction 2) and to a lesser extent, $\mathrm{HDL}_{2^{-}}$(fraction 3), but not $\mathrm{HDL}_{3^{-}}$(fraction 4) cholesterol. In light of the fact that the liver has a central role in VLDL assembly as well as LDL catabolism, the higher VLDL- and LDL-cholesterol content of birds fed on HC diets could simply be in response to an expanded hepatic cholesterol pool. If this occurred, the hypercholesterolaemia observed in these quail could then be explained by the increased VLDLTC, suggesting an impaired ability to clear VLDL-remnants as reflected by the enhanced LDL-TC also observed in the present study. The elevated LDL-TC in HC-fed quail is also similar to the hypercholesterolaemia reported in atherogenic pigeons, which was attributed to the expression of non-functional LDL-receptors rather than LDLreceptor down-regulation (Reagan et al. 1990). Similar findings have been reported in the Watanabe heritable hyperlipidaemic rabbit (Kita et al. 1981) and human subjects with familial hypercholesterolaemia (Thompson et al. 1981), both of which have defective receptormediated LDL clearance.

The interaction between the increased level of saturated fat from beef tallow and cholesterol supplementation of diets fed to quail observed for plasma TG levels but not cholesterol concentrations demonstrates a disparity in the metabolism of these two lipids. It is difficult to conclude that the interaction between dietary fat level and cholesterol intake for plasma TG resulted from enhanced lipogenesis, reduced fatty acid oxidation or increased secretion of VLDL, since these responses would also be expected to result in enhanced hepatic TG content (Grundy \& Denke, 1990; Fungwe et al. 1993), which did not occur in the present study. Since a dietary treatment interaction was not observed for hepatic TG, we can only conclude that dietary fatty acids are not as effective as de novo synthesized fatty acids as precursors for hepatic TG synthesis (Liu et al. 1995).

\section{Dietary cholesterol and aortic plaque score in quail}

The severity of atherosclerosis assessed by the visual scoring method of aortic lumen appearance was confirmed by scanning electron microscopy (figures available on request). The significance of these assessments is based on the findings of previous studies which have reported that atherogenesis in the Japanese quail is characterized by a series of events involving tissue disruption and swelling, followed by the appearance of cholesterol-laden foam cells and the formation of aortic plaque with cellular proliferation and narrowing of the lumen similar to the events occurring in human atherosclerosis (Shih et al. 1983; Peng et al. 1985). Previous in vitro studies with tissue from atherosclerosis-susceptible pigeons have demonstrated that aortic smooth muscle cells fail to internalize LDL due to the absence of a functional LDL-receptor pathway (Randolph $\&$ St Clair, 1984). It is noteworthy that the interaction noted between dietary saturated fat level and cholesterol intake for aortic plaque score coincided with a similar treatment interaction for plasma TG levels but not for plasma TC concentrations. The absence of atherosclerotic lesions in birds fed on the LC diets confirms the requirement for a high dietary cholesterol intake which results in both hypercholesterolaemia and hypertriacylglycerolaemia and, thereby, aortic plaque development. This hypothesis is supported by the low levels of tissue cholesterol and the absence of detectable cholesterol oxides in aortic tissue from LC-fed birds. Other studies conducted in the pigeon (Clarkson et al. 1962) and rabbit (Kritchevsky, 1970) also reported that the extent of atherosclerosis was greatest when diets were high in cholesterol; however, the effects on plasma TG were not assessed.

\section{Aortic tissue cholesterol and cholesterol oxide composition}

The detection of a greater number of cholesterol oxide species in atherosclerotic plaque material from quail fed on diet $\mathrm{E}$ paralleled the increased cholesterol content of these aortic tissues which were heavily covered by plaque. The presence of small but detectable concentrations of $7 \beta$ hydroxycholesterol, cholestanetriol, 7-ketocholesterol and 25-hydroxycholesterol in aortic plaque of birds fed on diet $\mathrm{E}$ occurred in addition to cholesterol-5, $6 \alpha$-epoxide, which was also detected in quail fed on the HC-low-beef-tallow 
diet (diet C). The fact that additional cholesterol oxides were present in aortic tissue collected from birds fed on diet $\mathrm{E}$ is further evidence of the atherogenic potential of the combination of a high cholesterol intake with increased presence of dietary saturated fat. The higher concentration of cholesterol and detection of cholesterol oxides in diseased aortas from quail that we report in the present study confirm the similarities in aortic plaque composition between this animal model and human atherosclerosis. Although previous workers have reported the recovery of cholesterol oxides from LDL extracted from human aortic plaque at autopsy (Steinbrecher \& Lougheed, 1992), our results show for the first time the important interaction between a high cholesterol intake combined with increased dietary energy derived from saturated fat on aortic plaque development and sterol composition in this animal model of human atherosclerosis.

\section{Conclusion}

In summary, atherosclerosis-susceptible Japanese quail fed on commercial Turkey Starter diets supplemented with $5.0 \mathrm{~g}$ cholesterol $/ \mathrm{kg}$ diet and a low or high level of saturated fat exhibited both hyperlipoproteinaemia and aortic plaque development. The hypertriacylglycerolaemia associated with cholesterol feeding was further enhanced in quail fed on beef tallow-supplemented diets, which supports the 'lipid hypothesis' that an increased intake of energy from saturated fat can increase plasma lipids and potentiate atherosclerosis. Moreover, the findings of a significant interaction between dietary cholesterol intake and saturated fat content observed for both plasma TG as well as aortic plaque score in Japanese quail strengthens the importance of plasma TG levels in reducing risk of coronary artery disease.

\section{Acknowledgements}

The authors are grateful for the assistance of Ms C. Nichols and Dr K. Cheng, University of British Colombia Quail Genetic Stock Research Centre and Dr G. Eigendorf, Department of Chemistry. This study was supported by grants obtained from the Dairy Farmers of Canada and the Natural Sciences and Engineering Research Council of Canada.

\section{References}

Austin MA (1991) Plasma triglyceride and coronary heart disease. Arteriosclerosis and Thrombosis 11, 2-14.

Bradford MM (1976) A rapid and sensitive method for the quantitation of microgram quantities of protein utilizing the principle of protein-dye binding. Analytical Biochemistry 72, 248-254.

Canadian Council of Animal Care (1993) Guide to the Care and Use of Experimental Animals, vol. 1, 2nd ed. [ED Olfert, BM Cross and AA MacWilliam, editors]. Ottawa, ON: Canadian Council of Animal Care.

Castelli WP (1986) The triglyceride issue: a view from Framingham. American Heart Journal 112, 432-437.

Clarkson TB, Prichard RW, Lofland HB \& Goodman HO (1962) Interactions among dietary fat, protein and cholesterol in atherosclerosis-susceptible pigeons. Circulation Research 11, 400404.

Faidley TD, Luhman CM, Galloway ST, Foley MR \& Beitz DC
(1990) Effect of dietary fat source on lipoprotein composition and plasma lipid concentrations in pigs. Journal of Nutrition 120, $1126-1133$

Fernandez ML \& McNamara DJ (1991) Regulation of cholesterol and lipoprotein metabolism in guinea pigs mediated by dietary fat quality and quantity. Journal of Nutrition 121, 934-943.

Fernandez ML \& McNamara DJ (1994) Dietary fat saturation and chain length modulate guinea pig hepatic cholesterol metabolism. Journal of Nutrition 124, 331-339.

Folch J, Lees M \& Sloane-Stanley GH (1957) A simple method for the isolation and purification of total lipides from animal tissues. Journal of Biological Chemistry 226, 497-509.

Fungwe TV, Cagen LM, Cook GA, Wilcox HG \& Heimberg M (1993) Dietary cholesterol stimulates hepatic biosynthesis of triglyceride and reduces oxidation of fatty acids in the rat. Journal of Lipid Research 34, 933-941.

Fungwe TV, Fox JE, Cagen LM, Wilcox HG \& Heimberg M (1994) Stimulation of fatty acid biosynthesis by dietary cholesterol and of cholesterol synthesis by dietary fatty acid. Journal of Lipid Research 35, 311-318.

Godin DV, Cheng KM, Garnett ME \& Nichols CR (1994) Antioxidant status of Japanese quail: comparison of atherosclerosissusceptible and -resistant strains. Canadian Journal of Cardiology 10, 221-228.

Grundy SM \& Denke MA (1990) Dietary influences on serum lipids and lipoproteins. Journal of Lipid Research 31, 11491172.

Hayes KC, Pronczuk A \& Khosla P (1995) A rationale for plasma cholesterol modulation by dietary fatty acids: modulating of human response in animals. Journal of Nutritional Biochemistry 6, 188-194.

Hunt CE, Funk GM \& Vidmar TJ (1992) Dietary polyunsaturated to saturated fatty acid ratio alters hepatic LDL transport in cynomolgus macaques fed low cholesterol diets. Journal of Nutrition 122, 1960-1970.

Keys A, Anderson JT, Mickelsen O, Adelson SF \& Fidanza F (1956) Diet and serum cholesterol in man: lack of effect of dietary cholesterol. Journal of Nutrition 59, 39-56.

Khosla P \& Hayes KC (1993) Dietary palmitic acid raises plasma LDL cholesterol relative to oleic acid only at a high intake of cholesterol. Biochimica et Biophysica Acta 1210, 13-22.

Kita T, Brown MS, Watanabe Y \& Goldstein JL (1981) Deficiency of low density lipoprotein receptors in liver and adrenal gland of the WHHL rabbit, an animal model of familial hypercholesterolaemia. Proceedings of the National Academy of Sciences USA 78, 2268-2272.

Kris-Etherton PM, Derr J, Mitchell DC, Mustad VA, Russell ME, McDonnell ET, Salabsky D \& Pearson TA (1993) The role of fatty acid saturation on plasma lipids, lipoproteins, and apolipoproteins: I. Effects of whole food diets high in cocoa butter, olive oil, soybean oil, dairy butter, and milk chocolate on the plasma lipids of young men. Metabolism 42, 121-129.

Kritchevsky D (1970) Role of cholesterol vehicle in experimental atherosclerosis. American Journal of Clinical Nutrition 23, $1105-1110$

Lin ECK, Fernandez ML \& McNamara DJ (1992) Dietary fat type and cholesterol quantity interact to affect cholesterol metabolism in guinea pigs. Journal of Nutrition 122, 2019-2029.

Lindsey S, Benattar J, Pronczuk A \& Hayes KC (1990) Dietary palmitic acid (C16:0) enhances high density lipoprotein cholesterol and low density lipoprotein receptor mRNA abundance in hamsters. Proceedings of the Society for Experimental Biology and Medicine 195, 261-269.

Lipid Research Clinics Program (1984) The lipid research clinics coronary primary prevention trial results. I: Reduction in incidence of coronary heart disease. Journal of the American Medical Association 251, 351-364. 
Liu CH, Huang M \& Huang P-C (1995) Sources of triacylglycerol accumulation in livers of rats fed on cholesterol-supplemented diets. Lipids 30, 527-531.

Mattson FH \& Grundy SM (1985) Comparison of effects of dietary saturated, monounsaturated, and polyunsaturated fatty acids on plasma lipids and lipoproteins in man. Journal of Lipid Research 26, 194-202.

Miller DS \& Payne PR (1959) A ballistic bomb calorimeter. British Journal of Nutrition 13, 501-508.

Mott GE, Jackson EM, McMahan CA \& McGill HC Jr (1992) Dietary cholesterol and type of fat differentially affect cholesterol metabolism and atherosclerosis in baboons. Journal of Nutrition 122, 1397-1406.

Mustad VA, Ellsworth JL, Cooper AD, Kris-Etherton PM \& Etherton TD (1996) Dietary linoleic acid increases and palmitic acid decreases LDL receptor protein and mRNA abundance in young pigs. Journal of Lipid Research 37, 2310-2323.

Mustad VA, Etherton TD, Cooper AD, Mastro AM, Pearson TA, Jonnalagadda SS \& Kris-Etherton PM (1997) Reducing saturated fat intake is associated with increased levels of LDL receptors on mononuclear cells in healthy men and women. Journal of Lipid Research 38, 459-468.

Nishina PM, Lowe S, Verstuyft J, Naggert JK, Kuypers FA \& Paigen B (1993) Effects of dietary fats from animal and plant sources on diet-induced fatty streak lesions in C57BL/6J mice. Journal of Lipid Research 34, 1413-1422.

Nwokolo E \& Kitts DD (1988) Growth parameters and plasmatissue fatty acid profiles of rats fed rubber seed oil. Food Chemistry 30, 219-229.

Ohtani H, Hayashi K, Hirata Y, Dojo S, Nakashima K, Nishio E, Kurushima H, Sacki M \& Kajiyama G (1990) Effects of dietary cholesterol and fatty acids on plasma cholesterol level and hepatic lipoprotein metabolism. Journal of Lipid Research 31, 1413-1422.

Patsch JR, Miesenboeck G, Hopferwieser T, Muehlberger V, Knapp E, Dunn JK, Gotto AM Jr \& Patsch W (1992) Relation of triglyceride metabolism and coronary artery disease. Studies in the postprandial state. Arteriosclerosis and Thrombosis 12, 1336-1345.

Peng S-K, Taylor CB, Hill JC \& Morin RJ (1985) Cholesterol oxidation derivatives and arterial endothelial damage. Atherosclerosis 54, 121-133.

Pronczuk A, Khosla P \& Hayes KC (1994) Dietary myristic, palmitic and linoleic acids modulate cholesterolemia in gerbils. FASEB Journal 8, 1191-1200.

Radcliffe JD \& Tromposch TS (1988) The effect of dietary cholesterol level on lipid status and initiation of atherosclerosis in Japanese quail. Nutrition Research 8, 1021-1027.

Randolph RK \& St Clair RW (1994) Pigeon aortic smooth muscle cells lack a functional low density lipoprotein receptor pathway. Journal of Lipid Research 25, 903-912.

Reagen JW Jr, Miller LR \& St Clair RW (1990) In vivo clearance of low-density lipoprotein in pigeons occurs by a receptor-like mechanism that is not down-regulated by cholesterol feeding. Journal of Biological Chemistry 265, 9381-9391.

Rokosova B, Rapp JH, Porter JM \& Bentley JP (1986) Composition and metabolism of symptomatic distal aortic plaque. Journal of Vascular Surgery 3, 617-622.
Schaefer EJ, Levy RI, Ernst ND, van Sant FD \& Brewer BH (1981) The effects of low cholesterol, high polyunsaturated fat, and low-fat diets on plasma lipid and lipoprotein cholesterol levels in normal and hypercholesterolemic subjects. American Journal of Clinical Nutrition 34, 1758-1763.

Seppanen-Laakson T, Vanhanen H, Laaksom I, Kohtamaki H \& Viikari J (1992) Replacement of butter on bread by rapeseed oil and rapeseed oil-containing margarine: effects on plasma fatty acid composition and serum cholesterol. British Journal of Nutrition 68, 639-654.

Shepherd J, Packard CJ, Grundy SM, Yeshurun A, Gotto M \& Taunton OD (1980) Effects of saturated and polyunsaturated fat diets on the chemical composition and metabolism of low density lipoproteins in man. Journal of Lipid Research 21, 91-99.

Shih JCH, Pullman EP \& Kao KJ (1983) Genetic selection, general characterization, and histology of atherosclerosis-susceptible and -resistant Japanese quail. Atherosclerosis 49, 41-53.

Siedel J, Hagele EO, Ziegenhorn J \& Wahlefeld AW (1983) Reagent for the enzymatic determination of serum cholesterol with improved lipolytic efficiency. Clinical Chemistry 29, 1075-1080.

Spady DK \& Dietschy JM (1985) Dietary saturated triacylglycerols suppress hepatic low density lipoprotein receptor activity in the hamster. Proceedings of the National Academy of Sciences USA 82, 4526-4530.

Spady DK \& Dietschy JM (1988) Interaction of dietary cholesterol and triacylglycerides on the regulation of hepatic low density lipoprotein transport in the hamster. Journal of Clinical Investigation 81, 300-309.

Steinbrecher UP \& Lougheed M (1992) Scavenger receptorindependent stimulation of cholesterol esterification in macrophages by low density lipoprotein extracted from human aortic intima. Arteriosclerosis and Thrombosis 12, 608-625.

Sundram K, Hayes KC \& Siru OH (1995) Both dietary 18:2 and 16: 0 may be required to improve the serum LDL/HDL cholesterol ratio in normocholesterolemic men. Journal of Nutritional Biochemistry 6, 179-187.

Takayama M, Itoh S, Nagasaki T \& Tanimizu I (1977) A new enzymatic method for determination of serum choline-containing phospholipids. Clinica Chimica Acta 79, 93-98.

Terpstra AHM, Sanchez-Muniz FJ, West CE \& Woodward CJH (1982) The density profile and cholesterol concentration of serum lipoproteins in domestic and laboratory animals. Comparative Biochemistry and Physiology 71B, 669-763.

Thompson GR, Souter AK, Spengel FA, Jadhav A, Gavigan SJP \& Myant NB (1981) Defects of receptor-mediated low density lipoprotein catabolism in homozygous familial hypercholesterolaemia and hyperthyroidism in vivo. Proceedings of the National Acadamy of Sciences USA 78, 25911-25915.

Yuan YV, Kitts DD \& Godin DV (1997) Influence of dietary cholesterol and fat source on atherosclerosis in the Japanese quail (Coturnix japonica). British Journal of Nutrition 78, $993-$ 1014.

Ziegenhorn J (1975) Improved method for enzymatic determination of serum triglycerides. Clinical Chemistry 21, 16271629. 